\title{
Using the United States Wind Turbine Database to Identify Increasing Turbine Size, Capacity and Other Development Trends
}

\author{
Chad Walker \\ Department of Geography, University of Exeter, Exeter, UK \\ Email:c.j.r.walker@exeter.ac.uk
}

How to cite this paper: Walker, C. (2020) Using the United States Wind Turbine Database to Identify Increasing Turbine Size, Capacity and Other Development Trends. Energy and Power Engineering, 12, 407-431. https://doi.org/10.4236/epe.2020.127025

Received: June 2, 2020

Accepted: July 24, 2020

Published: July 27, 2020

Copyright $\odot 2020$ by author(s) and Scientific Research Publishing Inc. This work is licensed under the Creative Commons Attribution International License (CC BY 4.0).

http://creativecommons.org/licenses/by/4.0/

\begin{abstract}
The purpose of this article was to analyze data associated with advances in wind energy across the United States. While governments, academia, and the private sector generally know patterns of wind turbine development (i.e. turbine size and capacity growing in recent years), there is no known independent, reliable, and/or updated summary of these variables. Using data collected by the Lawrence Berkeley National Laboratory and partners, this study used descriptive statistics to show turbine development and growth patterns from 1981-2019. The newly created United States Wind Turbine Database (USWTDB) represents the most comprehensive account of wind turbine information and was updated in January 2020. Variables I am interested in here are turbine manufacturer, state of project, turbine and project capacity, and turbine size. Findings provide empirical evidence to support the common, yet previously unrefined statements that wind turbines are growing larger in number, size and capacity. This growth is varied over spatial and temporal scales. I also provide evidence to show patterns of turbine manufacturing, with GE Wind dominating much of the US wind energy landscape today. I hope this work provides a timely resource for those interested in a variety of questions surrounding wind energy development in the United States. Perhaps more importantly, this analysis will hopefully inspire others to use what the USWTDB provides and answer larger questions surrounding wind energy futures.
\end{abstract}

\section{Keywords}

Wind Energy, Wind Turbines, USWTDB, Renewable Energy, Turbine Capacity, Turbine Size

\section{Introduction}

Responding to intersecting problems including global climate change, air pollu- 
tion, and domestic energy insecurity, wind energy has emerged as a major source of low-carbon electricity generation. In the United States alone, there are now more than 60,000 utility-scale turbines, representing nearly 100 gigawatts of wind energy capacity and $15 \%$ of the global total [1] [2]. Much of this has been introduced over the past decade, and yet up until recently, there was no publicly accessible dataset that described wind turbines and their characteristics (e.g. size, capacity, location). Recognizing this void, researchers across three organizationsthe Lawrence Berkeley National Laboratory (LBNL), the United Stated Geological Survey (USGS), and the American Wind Energy Association (AWEA)came together in 2018 to create such a dataset. Aptly named The US Wind Turbine Database (USWTDB), information is provided on turbines dating back to 1981 and is updated on a quarterly basis. Apart from the USWTDB Viewer [3], which provides a simple and interactive way for anyone to visualize wind turbines across the country, there is no known resource for those who want to understand trends in US wind energy growth. More specifically, the Viewer and any other known resources do not provide any way to understand summarized and/or precise changes to US wind energy landscapes.

In this paper, I use the USWTDB to analyze patterns of US wind energy growth over four decades. For government, this will help those who debate and design policy. In industry, this may help businesses of all sizes understand current (and perhaps future) landscapes of the sector. For academics, I see this paper as providing an important starting-point for discussions around the clustering, size, and growing capacity of wind turbines. Echoing the benefits described by Rand et al. [2], this paper may also provide important context for groups interested in: climate change and air quality [4], local health and well-being [5], grid impacts [6], land requirements [7], local surface temperatures [8], sound and noise [9], property values [10] [11], renewable energy potentials [12], and acceptance research [13] [14] [15].

For all of these groups listed above-and more-there is a general understanding that turbines are getting larger in both in size, capacity and overall number. Yet, there is still a need for a study that analyses these trends in a systematic way. I answer what I see is a call for this kind of resource. In doing so, I provide a clear, accessible, and available-to-all report.

\section{Methods}

\subsection{United States Wind Turbine Database}

A full description of the USWTDB, including its process of creation, can be found in a recent publication by Rand et al. [2]. Here, I simply wish to clarify some important issues that directly relate to the variables used in this analysis. First, for many of the most pertinent variables, the USWTDB authors provide us their level of confidence ( $0=$ not verified; $1=$ no confidence; $2=$ partial confidence; 3 = full confidence) regarding turbine characteristics (e.g. size, capacity, model, project name) and turbine location (coordinates). Of the total of 63,003 
turbines, there was full confidence in turbine characteristics of $81 \%$ (9.5\% with partial and 9.5\% with no confidence). In terms of location, there was full confidence throughout $92.8 \%$ of the data $(0.6 \%$ with partial and $6.5 \%$ with no confidence). This leaves us confident in the characteristics of 51,037 turbines and in the location of 58,494 turbines [2].

In most of the analysis here, I include only those turbines/projects with the highest level of confidence. This ensures transparency and should increase the reader's trust in the findings. Exceptions are seen when characteristics of wind turbines are not necessary (i.e. total number of turbines). As per the USWTDB, dismantled turbines are not included, but decommissioned turbines are. Residential-scale turbines (usually less than $65 \mathrm{~kW}$ and 30 metres in height) are not included in the dataset. Some exceptions to this may include smaller wind turbines built in California before 1990. At the time, these were considered to be utility-scale and thus are retained in the USWTDB.

\subsection{Data Analysis}

On March 28 2020, the USWTDB data was downloaded and input into SPSS 24 software. Based on Rand et al. [2] and verification of the data itself, the USWTDB included all turbines built and constructed by the end of 2019. The oldest wind turbines date back to 1981 (no confidence in turbine characteristics) or 1982 (full confidence in characteristics or any confidence in turbine location).

Before analysis took place, the dataset was cleaned to remove any missing variables. This was done for the variables of project year operational, project capacity, turbine capacity, turbine hub height, turbine rotor diameter, and turbine rotor swept area. I then used simple descriptive statistics to identify trends in the dataset. Based on a combination of what I saw as gaps in the literature, and what the dataset provided, this includes: leading turbine manufacturers, turbine capacity by year, the (physical) growth of wind turbines, and wind energy development by state (by year and decade). Below I present figures and tables that summarize such findings. Complete results of each section (via tables) can be found in the Appendix A-H [3].

\section{Results}

\subsection{Wind Turbine Manufacturers}

As of the end of 2019, General Electric (GE) Wind was by far the leading manufacturer of wind turbines across the United States (see Figure 1). Of the more than 51,000 turbines with full characteristics confidence, the company produced 21,774 (41.5\%). Vestas (including Vestas North America; $24.1 \%$ or 12,322) produced the next highest number. At 4901 (9.6\%), Siemens came in third. Though due to a 2017 merge with Gamesa (which later became Siemens Gamesa Renewable Energy), it may be argued that the new company is actually responsible for a total of 8137 turbines (15.9\%) as of 2019. Mitsubishi (5.5\%), Gamesa (5.2\%), Suzlon (2.6\%), Nordex (1.8\%), Acciona (1.5\%), NEG Micon (1.3\%), 
Clipper (1.3\%), Siemens Gamesea Renewable Energy (1.1\%), and Repower (1.1\%) represent the top 12 and include all those with at least $1 \%$ of turbines. A list of all those companies with at least five turbines as of 2019 ( $0.1 \%$ of total) can be found within the Appendix B.

We can also look for recent changes in the above trends. As of 2009, things were much the same. GE Wind was still the leader (36.2\%). Vestas was second (22.5\%), followed by Mitsubishi (11.6\%) and Siemens (6.1\%). Going back two decades to 1999 , Vestas was the undisputed leader with near a third $(32.5 \%)$ of all turbines. Enron (20.5\%) and NEG Micon (17.6\%) followed.

\subsection{Growth of New Turbine Capacity and Total Number of Turbines}

Figure 2 shows the annual growth of average new turbine capacity and the annual number of new turbines. Because of gaps in data for turbine capacity through the 1980s and 1990s, here I include both the values given with full and partial confidence. The full dataset that makes up Figure 2 can be found within the Appendix C.

Of the 51,036 turbines with full confidence in capacity, the average (mean) turbine capacity was $1831.85 \mathrm{~kW}(1.85 \mathrm{MW})$. Though as the figure shows, this has varied throughout time. In 1990, the average turbine was just $218.16 \mathrm{~kW}$ (0.218 MW). In 2005, this reached nearly 1.5 MW. In 2014, this rose to $1.93 \mathrm{MW}$ and finally in 2019 , the steady rise continued, with the average turbine having a capacity of 2.56 MW. The turbine with the largest capacity (of all years) became operational in 2016 and had a capacity of 6 MW. It was associated with a five-turbine project called Block Island (Washington County, Rhode Island).

Using an expanded set of all development, we see the number of turbines has generally grown year over year-but with some notable spikes and valleys. Up until 2000, new turbines averaged just under 300 per year. There were just two years in this set of 18 that saw more than 1000 turbines becoming operational1985 ( $\mathrm{n}=1596$; all of which occurred across 16 wind farms in California), and

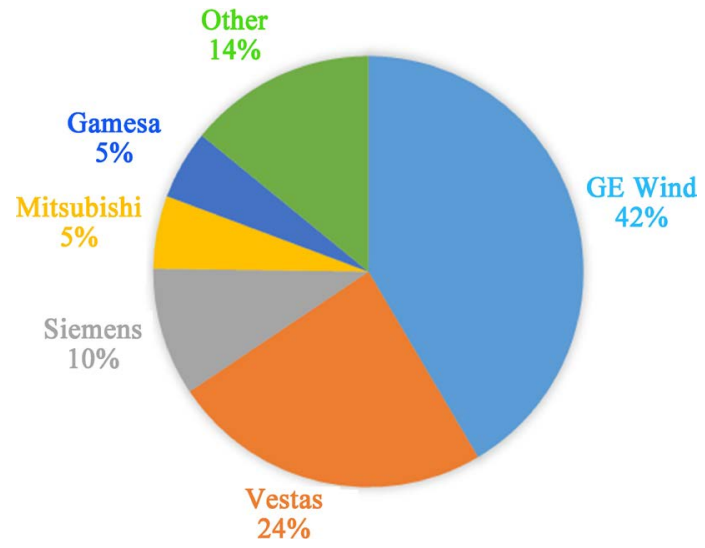

${ }^{*}$ Of the total number of wind turbines as of $2019(n=51,036)$. Though there were 51,037 turbines with full confidence in turbine characteristics, we found one turbine manufacturer as "missing". This may have been caused by a coding error.

Figure 1. Wind Turbines by manufacturer (percent of total ${ }^{\star}$ ). 


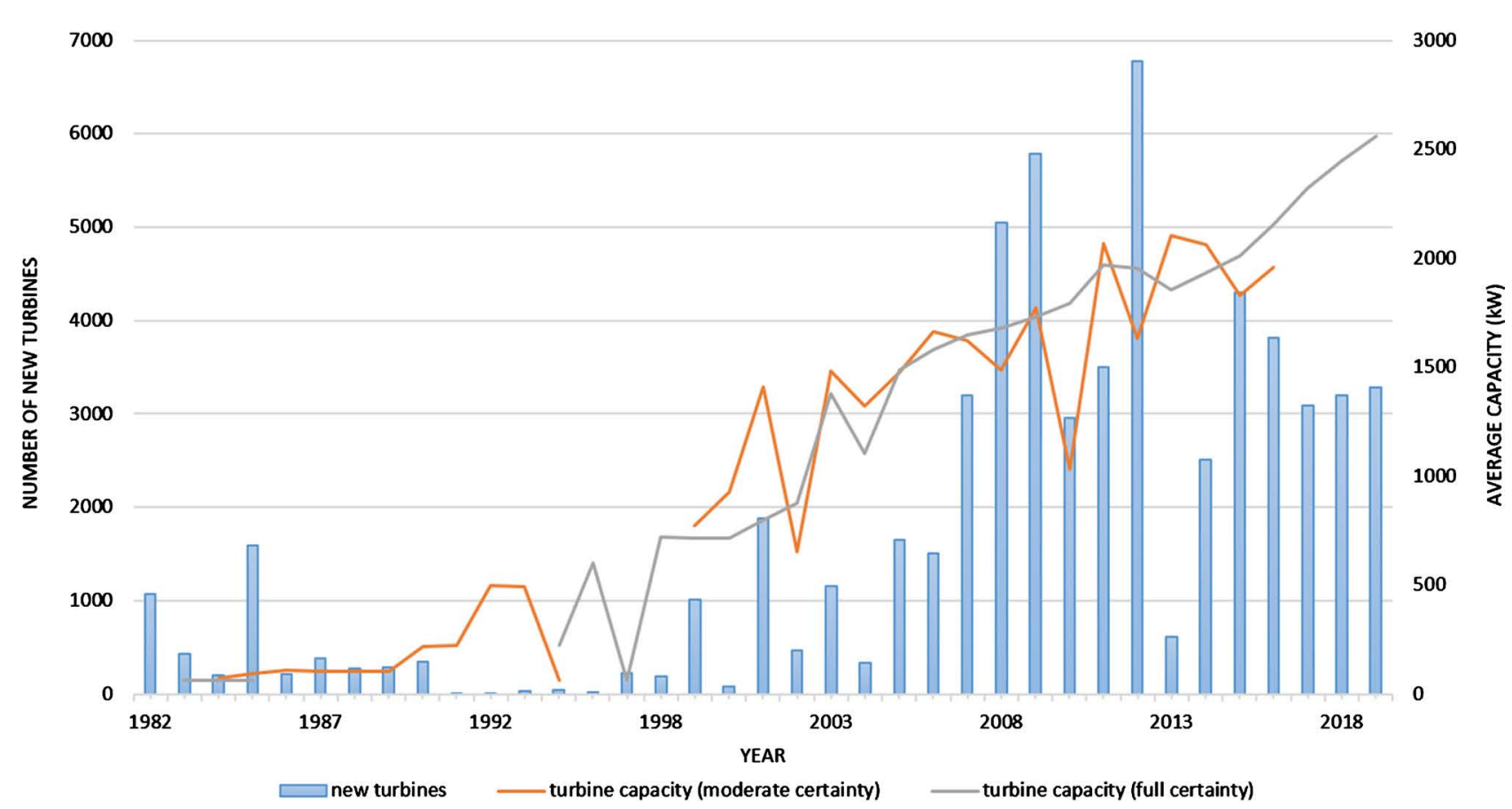

${ }^{*}$ For the year 1989, there was no information about average turbine capacity so I chose to insert a value that is equal to the average of the three preceding years. There were no turbines built in 1993 throughout the entire database, and so that year is not given a value (i.e. the year is ignored).

Figure 2. Number of wind turbines and average capacity (by year)*.

1999 ( $\mathrm{n}=1005$; where 33 wind farms were built in 10 states).

From 2001 to 2019, the average number of turbines was 2897/year-though again with great variation. 2001 saw 1876 new turbines-a value that was not exceeded until 2007 when 3200 turbines became operational. This growth would continue until $2010(\mathrm{n}=5780)$, when average turbines built from 2010-2011 dropped to just 3232. A recovery in 2012 marked the highest number of turbines ever built $(n=6774)$. Aside from a severe drop the following year $(n=610)$, new turbines have been relatively stable in recent history. This includes an average of 3366 turbines from 2014 to 2019.

\subsection{Wind Turbine Development by State}

Given our understanding of the general growth of wind energy, it is important to recognize the geographic distribution of wind turbine development (i.e. by state; see Figure 3 and Appendix D). Using the USWTDB's list of all turbines with a state/territory given, there are a few trends that stand out.

First is the dominance of California during the first two decades. From 19811991, California accounted for all new wind turbines $(n=4819$; not shown). The late 1990s and 2000s brought with them much more diversity across the US energy landscape. By the end of 2009, there were 38 states with at least one turbine. Texas ( $\mathrm{n}=6094$ or $22.2 \%$ ) was just trailing behind California $(\mathrm{n}=6278$ or $22.9 \%)$ as the nation's leader. Other significant development had taken place in Iowa (9.2\%), Minnesota (4.9\%), Oregon (4.5\%) and Washington state (4.3\%).

From 2011-2019 there had been substantial growth in wind energy across the 


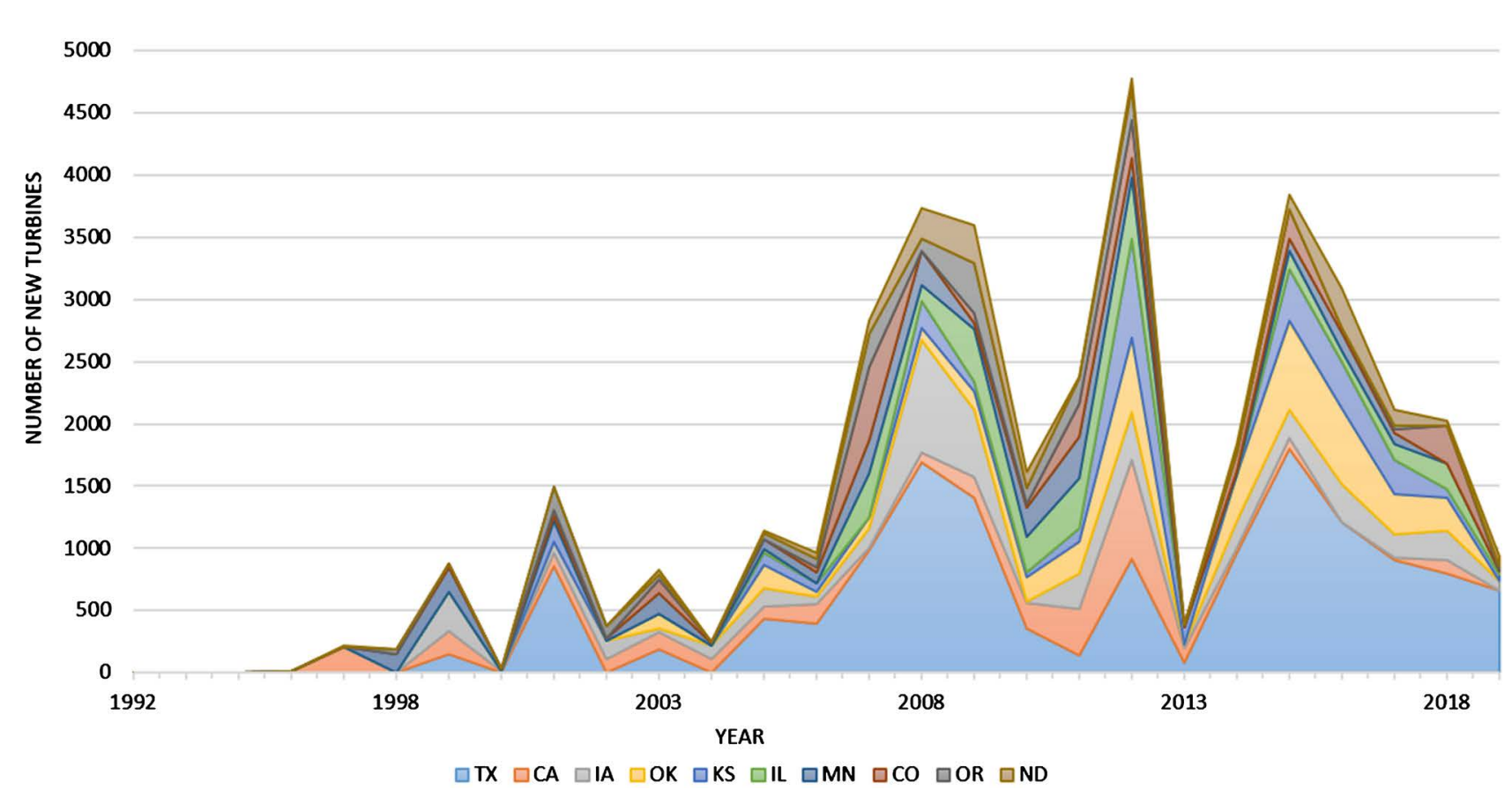

Figure 3. Number of new wind turbines by state and year (1992-2019; Top 10 states as of 2019).

United States. Again, when using the dataset of all turbines, there is a $2.24 \mathrm{x}$ increase in wind turbines from 2009 to 2019-strongly aided by "spikes" in 2012 and 2015. By the end of 2019, Texas was the leader in wind turbines $(\mathrm{n}=14,852$ or $24.2 \%$ ) while California was a distant second (13\%). Iowa was in third (8.7\%) and Oklahoma moved to fourth (6.6\%). As of 2019, there were 22 states with at least $1 \%$ of all turbines. There were 40 states and 2 territories (Puerto Rico and Guam) with at least one turbine.

\subsection{Total Wind Energy Capacity by State}

While the growth in number of turbines tells us something about the way wind energy development has taken place over the United States (Figure 3 and Appendix D), it is also helpful to understand the geographic distribution of wind energy capacity as well (Figure 4). That is because especially valuable given that more recently built turbines have capacities 5-6× larger than those from the 1980s (see Figure 2). Figures 4-6 below show the top 10 leading states in terms of total wind energy capacity-as well as total turbines and average turbine capacities-built in the 1990s, 2000s, and 2010s. The full dataset can be found in Appendix E.

Due to a concentration of new wind farms in Minnesota and Iowa in the late 1990s, both states overtook California by 2000 . While still behind in total number of turbines, advancements in wind energy technology (re: capacity) allowed for this to happen. In line with Figure 3, from 2010 onwards Texas also became the undisputed leader in terms of capacity-with nearly $8000 \mathrm{MW}$ in 2010 and nearly 25,000 MW by the end of 2019. Other notable states to emerge as wind energy leaders over the past decade include Oklahoma $(\mathrm{n}=7033.33 \mathrm{MW})$ and 


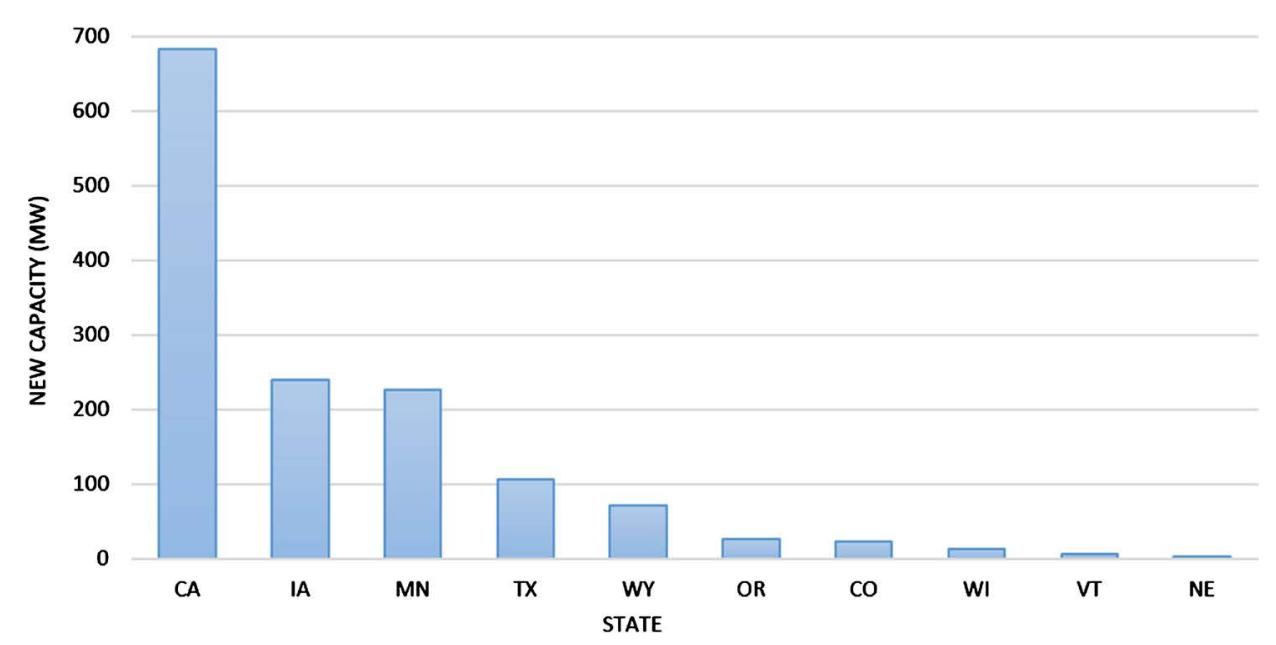

Figure 4. Total new wind energy capacity in the 1990s by state (Top 10 states in the 1990s).

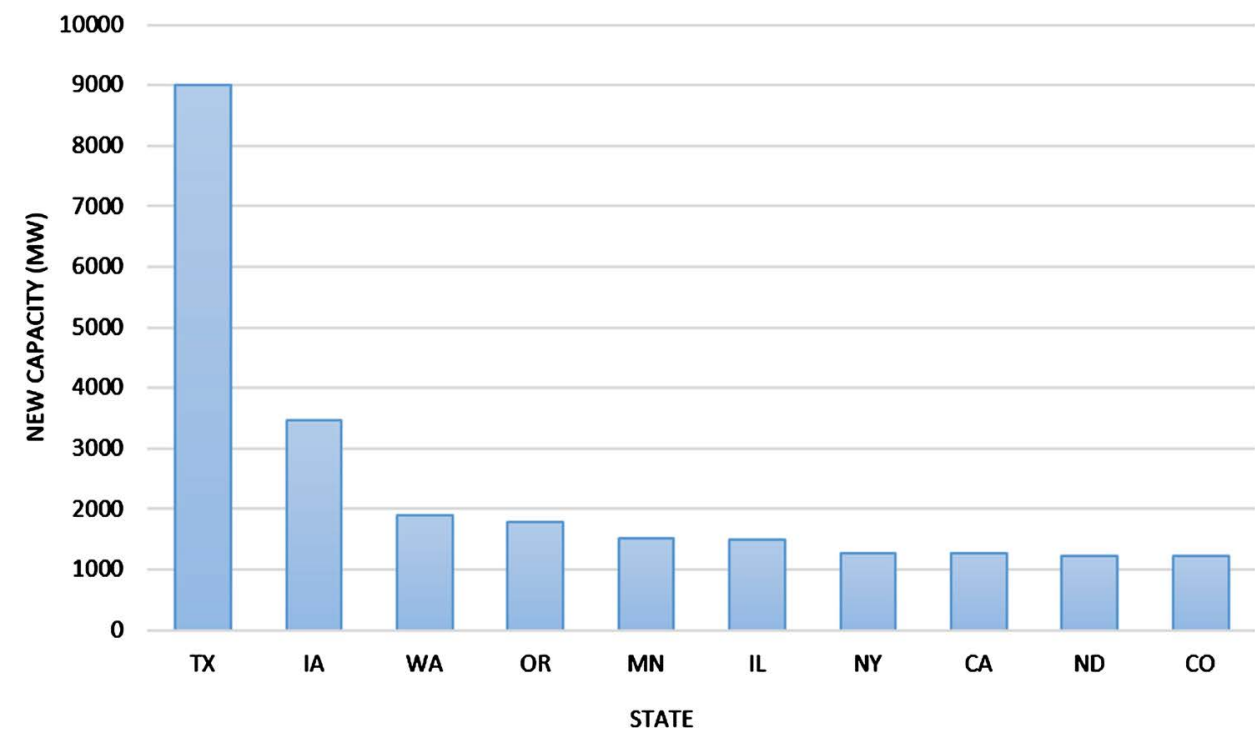

Figure 5. Total new wind energy capacity in the 2000s by state (Top 10 states in the 2000s).

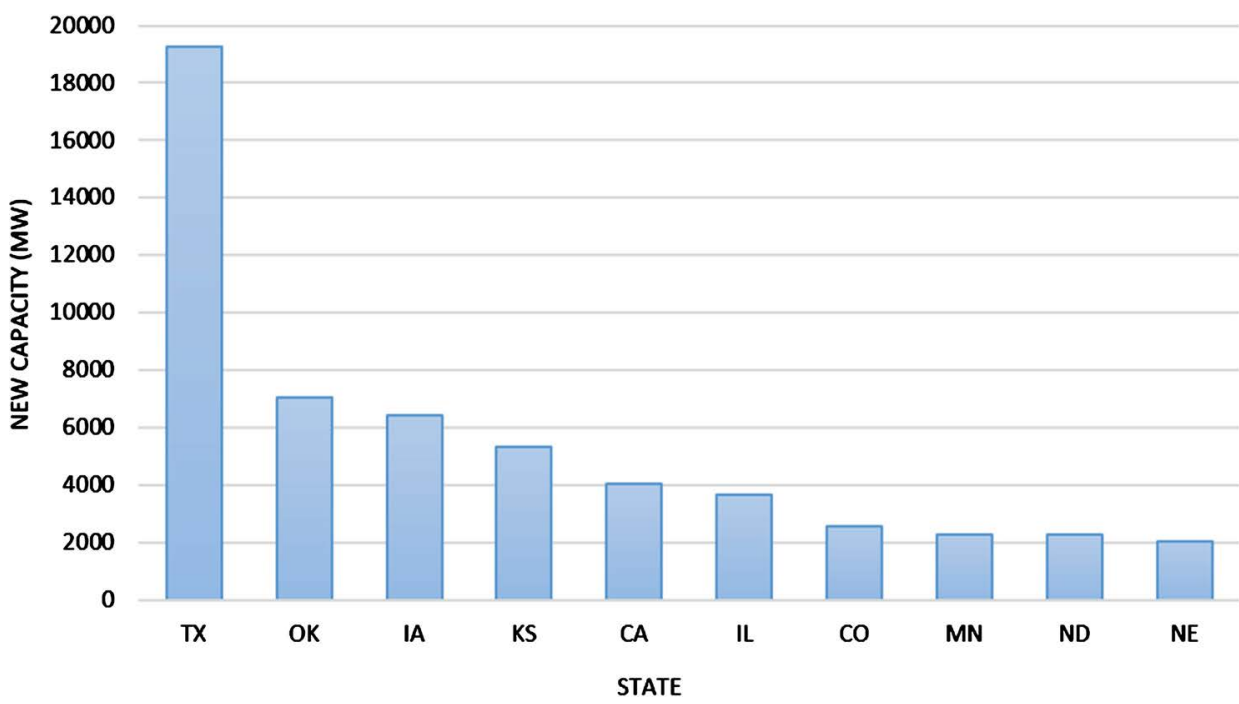

Figure 6. Total new wind energy capacity in the 2010s by state (Top 10 states in the 2010s). 
Kansas $(\mathrm{n}=5331.98 \mathrm{MW})$.

\subsection{Turbine Size by Year}

Finally, and corresponding to the growing capacity of wind developments, new turbines have grown in physical size since the 1980s. When using looking at hub height (i.e. the distance from the ground to the nacelle or centre of the wind turbine) there has been a $3.7 \times$ increase from 1985 (24.4 metres) to 2019 (90.3 metres). In looking at Figure 7 below (see also Appendix F), this rise has also been relatively constant, especially over the past 20 years. Again, due to inconsistencies in the data, I use turbine hub height data with full $(n=51,032)$ and partial $(\mathrm{n}=4168)$ confidence.

Using only those turbines with full confidence in hub heights, as of 2019 the largest onshore wind turbine has a hub height of 130 metres and is single turbine part of the UL Advanced Wind Turbine Test Facility (built in 2018 in Randall County, Texas). This is a $1.6 \times$ increase since the early to mid-2000s, where the largest hub heights were 80 metres (see Figure 8 below). Today, there are 1482 turbines with a hub height of 100 metres or more. The multi-turbine wind development with the largest hub heights is the Hancock Wind Farm (Hancock County, Maine), which has 17, 116.5-metre turbines. More information on tallest turbines (per year), can be found in Appendix G.

Although it is the most common approach, hub height is just one way to measure turbine size. Rotor diameter and turbine rotor swept area, which is the total area covered through one full rotation of turbine blades, are also used. Looking at only those turbines with full characteristics confidence, we can see the rise of both of these values over the past two decades (see Figure 9 and Appendix $\mathrm{H}$ ).

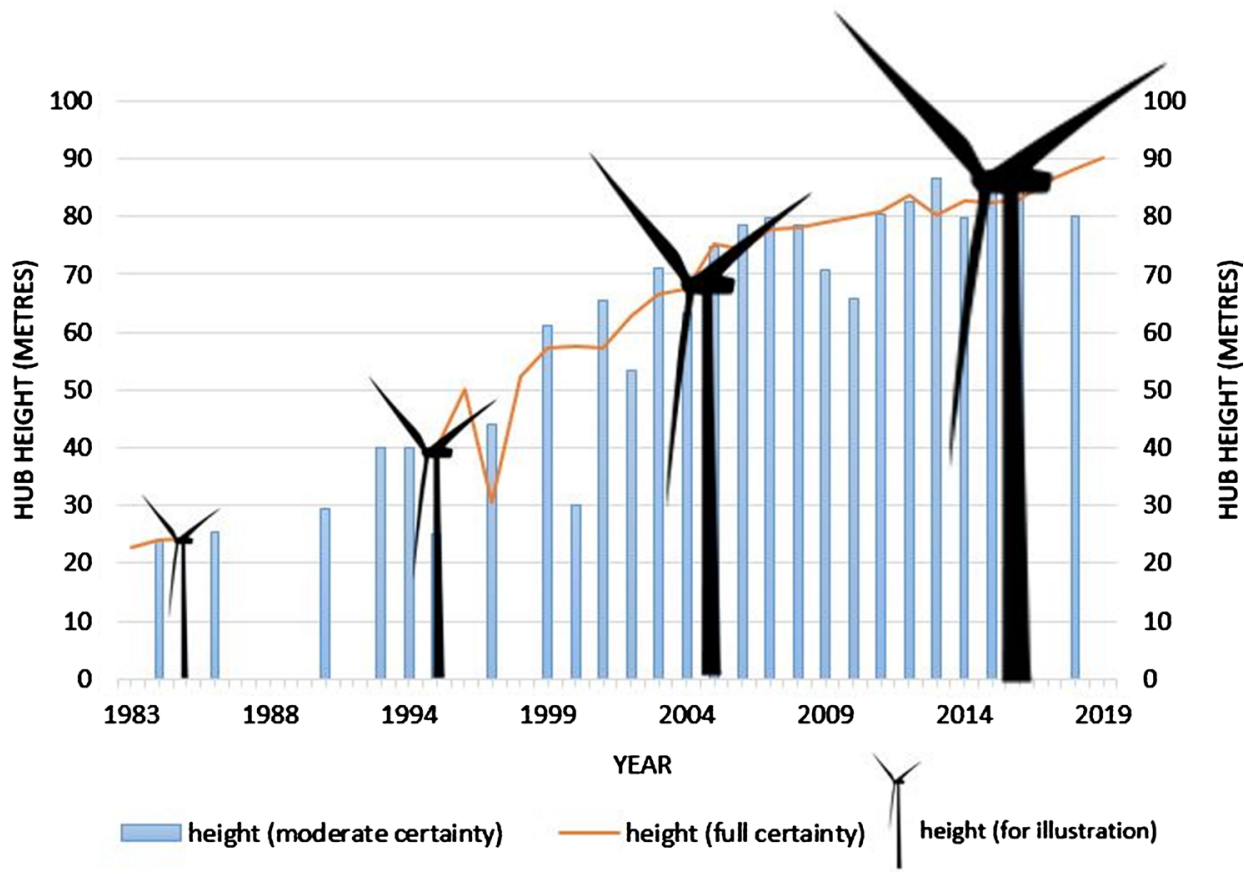

Figure 7. New turbine hub height (average) by year. 


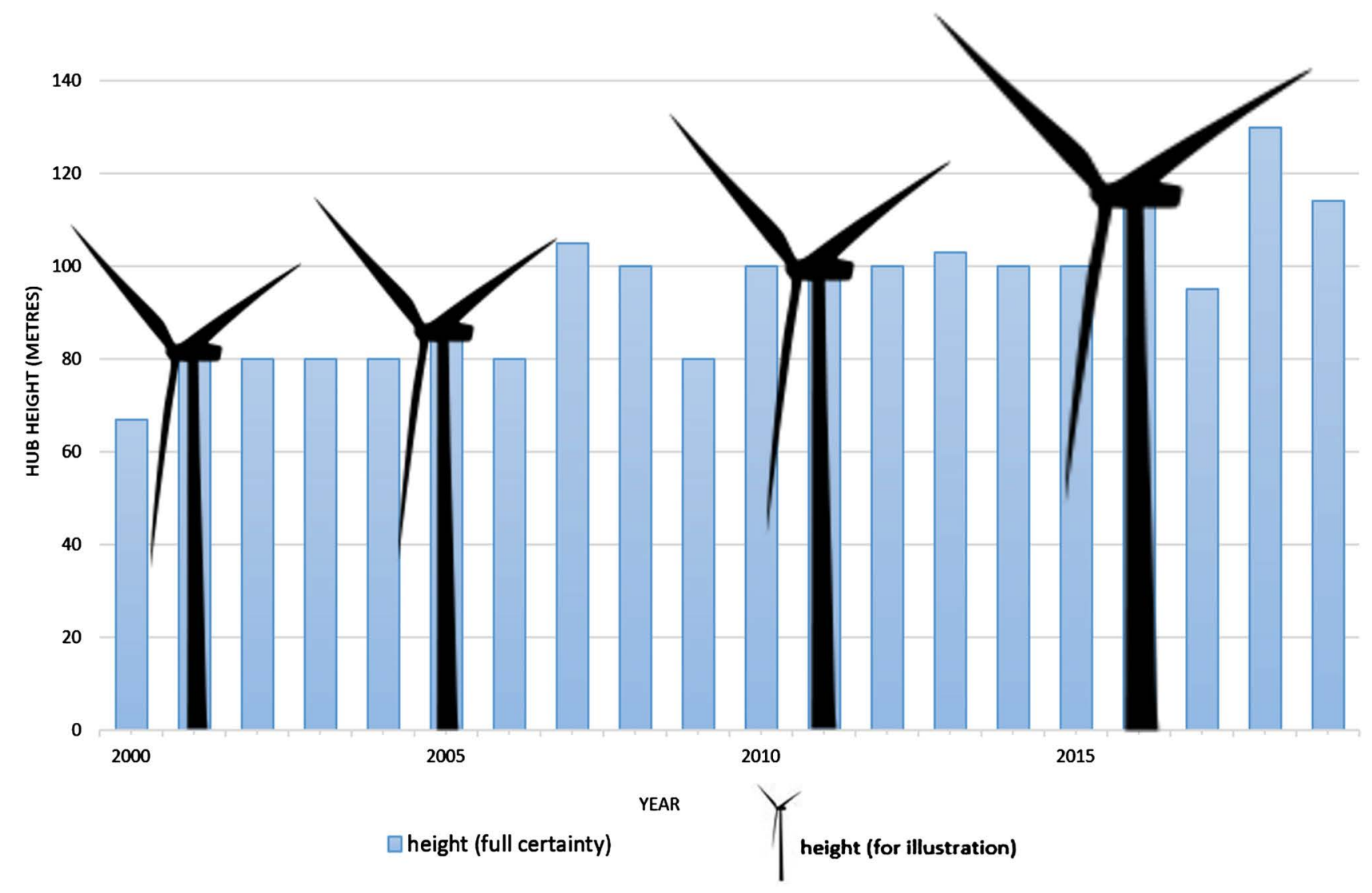

Figure 8. Largest turbine hub height (by year).

140

14000

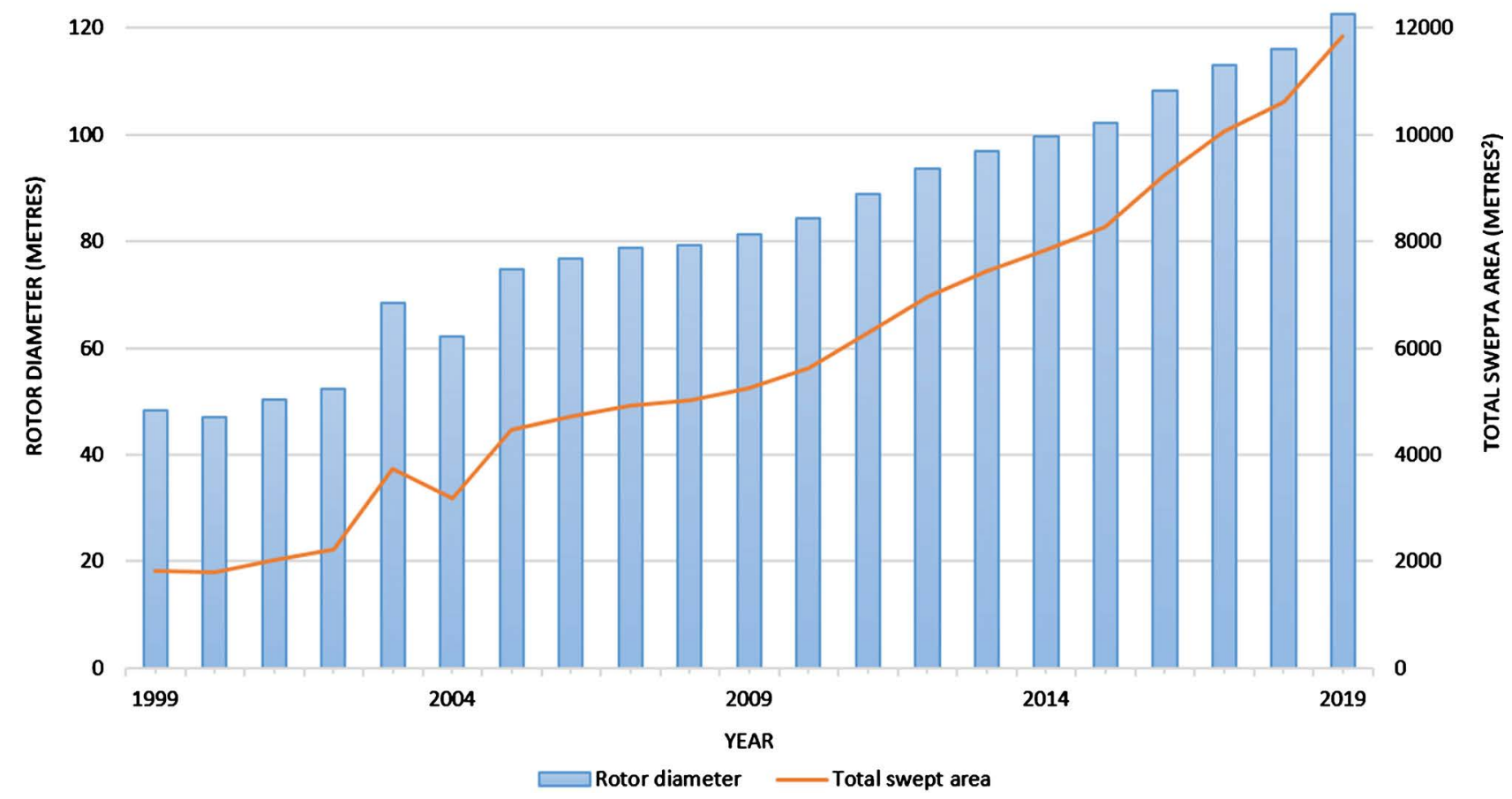

Figure 9. Average rotor diameter and total swept area by year. 
Average rotor diameter increased from 48.22 metres in 1999 to 122.63 metres in 2019. The largest diameters during this same period ranged from 66 metres in 1999 to 150 metres (GE Haliade 150-6) in 2016.

Total swept area is a direct function of turbine diameter and thus why we see a perfect association between the two values in Figure 9. The total swept area is calculated by dividing the rotor diameter by two (i.e. to get radius/blade length), multiplying that value by itself, and then multiplying by the value of $\mathrm{Pi}$ (approx. 3.14159). It is represented through the following equation:

$$
\text { Total swept area }=\pi *(\text { rotor diameter } / 2)^{2}
$$

\section{Discussion and Conclusions}

Here I have presented a paper that has highlighted some major trends related to wind energy development across the United States. This was enabled by the newly-published United States Wind Turbine Database-an important, yet previously unsynthesized resource.

I have begun this important work here, quantifying patterns of wind energy growth in terms of variables such as total number of turbines, capacity, geographic distribution, and size. In existing literatures, these factors are often written about as assumptions. That is, phrases like "as turbines grow larger in size"without quantification or citation-are increasingly common. I attempt to help move past the tendency to write in this way. More specifically, I show that in terms of manufacturing, and with $42 \%$ of the total, GE Wind is the undisputed leader as of 2019. Despite some significant peaks and valleys, the number of US turbines has generally increased year over year-with an average of over 3300 from 2014-2019. Average turbine capacity has also increased over the past four decades, and is now at just over 2.5 MW. In terms of geographic distribution, California may be labelled as the "early adopter" of wind energy, dominating all (small turbine) developments throughout the 1980s and much of the 1990s. Since then, Texas-and states like Iowa, Oklahoma and Kansas to smaller degree-have challenged and surpassed the "Golden State" in terms of both number of turbines and/or total capacity. Finally, I confirm the popular refrain of turbines getting physically larger since the 1980s. Growth of hub heights, rotor diameters and (thus) total swept areas, have seen very consistent growth over nearly 40 years. The largest turbines are now more than twice as tall (up to 130 metres) as they were just 20 years ago. Turbine rotor (blade) diameters have risen from approximately 50 metres in the early 2000s to just over 120 meters in 2019.

There are a few clear limitations of this study, some of which provide opportunities for further research. First, regarding the USWTDB itself, it included turbines that had been decommissioned. It would have been ideal if the dataset only included operational turbines, however even when not "spinning", there is an impact living near these structures. I suggest the USWTDB is edited to allow for analysis that identifies operational turbines, so that certain research questions would benefit as such. Second, and despite their best efforts [2], there were still 
some significant gaps in data throughout the USWTDB. These were especially prevalent throughout the 1980s and 1990s, so future research that depends on precise trends may want to focus on the past two decades only. Lastly, because the data only covered one country-albeit an important one in terms of global wind energy capacity - the results here are really only relevant to studies or reports that happen within the US. That said, and assuming there are similar datasets elsewhere, I hope this analysis inspires others to summarize the major trends in their jurisdiction.

All of these findings shared here should support a wide variety of actors-including governments, industry, and researchers-across an even wider area of inquiry. Given my expertise in the social acceptance of wind energy research [13] [14] [15], I see particular value to researchers here. I also want to highlight the opportunity for this research, and indeed the rich USWTDB as a whole, to help provide important context for a range of quantitative and qualitative studies. In the former, the dataset could be combined with other survey work. Fruitful research in this area could include health surveys and/or real estate sales data. In the qualitative realm, this data can also provide important context for case study research. For example, it may offer some important wind-farm specific characteristics that can help shape a common understanding of local development.

\section{Acknowledgements}

The author would like to thank the reviewers and editors with Energy and Power Engineering. Thanks also to the Lawrence Berkeley National Laboratory, the United States Geological Survey, and the American Wind Energy Association who are responsible for creating the United States Wind Turbine Database and thus enabled this research to take place.

\section{Conflicts of Interest}

The author declares no conflicts of interest regarding the publication of this paper.

\section{References}

[1] Global Wind Energy Council (GWEC) (2019) GWEC: Over 60 GW of Wind Energy Capacity Installed in 2019, the Second Biggest Year in History.

https://gwec.net/gwec-over-60gw-of-wind-energy-capacity-installed-in-2019-the-se cond-biggest-year-in-history

[2] Rand, J., Kramer, L., Garrity, C., et al. (2020) A Continuously Updated, Geospatially Rectified Database of Utility-Scale Wind Turbines in the United States. Scientific Data, 7, Article No. 15. https://doi.org/10.1038/s41597-020-0353-6

[3] United States Geological Survey (USGS) (2020) USWTDB Viewer. https://eerscmap.usgs.gov/uswtdb/viewer/\#3/37.25/-96.25

[4] Millstein, D., Wiser, R., Bolinger, M. and Barbose, G. (2017) The Climate and AirQuality Benefits of Wind and Solar Power in the United States. Nature Energy, 2, Article No. 17134. https://doi.org/10.1038/nenergy.2017.134 
[5] Walker, C., Baxter, J. and Ouellette, D. (2015) Adding Insult to Injury: The Development of Psychosocial Stress in Ontario Wind Turbine Communities. Social Science \& Medicine, 133, 358-365. https://doi.org/10.1016/j.socscimed.2014.07.067

[6] Johlas, H., Witherby, S. and Doyle, J. (2020) Storage Requirements for High Grid Penetration of Wind and Solar Power for the MISO Region of North America: A Case Study. Renewable Energy, 146, 1315-1324.

https://doi.org/10.1016/j.renene.2019.07.043

[7] Arent, D., Pless, J., Mai, T., et al. (2014) Implications of High Renewable Electricity Penetration in the US for Water Use, Greenhouse Gas Emissions, Land-Use, and Materials Supply. Applied Energy, 123, 368-377. https://doi.org/10.1016/j.apenergy.2013.12.022

[8] Miller, L. and Keith, D. (2018) Climatic Impacts of Wind Power. Joule, 2, 26182632. https://doi.org/10.1016/j.joule.2018.09.009

[9] Haac, T., Kaliski, K., Landis, M. et al. (2019) Wind Turbine Audibility and Noise Annoyance in a National US Survey: Individual Perception and Influencing Factors. The Journal of the Acoustical Society of America, 146, 1124-1141. https://doi.org/10.1121/1.5121309

[10] Hoen, B., Brown, J., Jackson, T., Thayer, M., Wiser, R. and Cappers, P. (2015) Spatial Hedonic Analysis of the Effects of US Wind Energy Facilities on Surrounding Property Values. The Journal of Real Estate Finance and Economics, 51, 22-51. https://doi.org/10.1007/s11146-014-9477-9

[11] Walker, C., Baxter, J., Mason, S., Luginaah, I. and Ouellette, D. (2014) Wind Energy Development and Perceived Real Estate Values in Ontario, Canada. AIMS Energy, 2, 424-442. https://doi.org/10.3934/energy.2014.4.424

[12] Oakleaf, J., Kennedy, C., Baruch-Mordo, S., et al. (2019) Mapping Global Development Potential for Renewable Energy, Fossil Fuels, Mining and Agriculture Sectors. Scientific Data, 6, 1-17. https://doi.org/10.1038/s41597-019-0084-8

[13] Rand, J. and Hoen, B. (2017) Thirty Years of North American Wind Energy Acceptance Research: What Have We Learned? Energy Research \& Social Science, 29, 135-148. https://doi.org/10.1016/j.erss.2017.05.019

[14] Walker, C., Baxter, J. and Ouellette, D. (2014) Beyond Rhetoric to Understanding Determinants of Wind Turbine Support and Conflict in Two Ontario, Canada Communities. Environment and Planning A, 46, 730-745. https://doi.org/10.1068/a130004p

[15] Baxter, J., Walker, C., Ellis, G., Devine-Wright, P., Adams, M. and Fullerton, R.S. (2020) Scale, History and Justice in Community Wind Energy: An Empirical Review. Energy Research \& Social Science, 68, Article ID: 101532. https://doi.org/10.1016/j.erss.2020.101532 


\section{Appendix}

A. State and Territories: Abbreviations

\begin{tabular}{|c|c|}
\hline STATE & Abbreviation \\
\hline Alabama & $\mathrm{AL}$ \\
\hline Alaska & $\mathrm{AK}$ \\
\hline Arizona & $\mathrm{AZ}$ \\
\hline Arkansas & $\mathrm{AR}$ \\
\hline California & $\mathrm{CA}$ \\
\hline Colorado & $\mathrm{CO}$ \\
\hline Connecticut & CT \\
\hline Delaware & $\mathrm{DE}$ \\
\hline District of Columbia & $\mathrm{DC}$ \\
\hline Florida & FL \\
\hline Georgia & GA \\
\hline Guam & GU \\
\hline Hawaii & HI \\
\hline Idaho & ID \\
\hline Illinois & $\mathrm{IL}$ \\
\hline Indiana & IN \\
\hline Iowa & IA \\
\hline Kansas & KS \\
\hline Kentucky & KY \\
\hline Louisiana & LA \\
\hline Maine & $\mathrm{ME}$ \\
\hline Maryland & MD \\
\hline Massachusetts & MA \\
\hline Michigan & MI \\
\hline Minnesota & $\mathrm{MN}$ \\
\hline Mississippi & MS \\
\hline Missouri & MO \\
\hline Montana & MT \\
\hline Nebraska & $\mathrm{NE}$ \\
\hline Nevada & NV \\
\hline New Hampshire & $\mathrm{NH}$ \\
\hline New Jersey & NJ \\
\hline New Mexico & $\mathrm{NM}$ \\
\hline New York & NY \\
\hline North Carolina & NC \\
\hline
\end{tabular}




\section{Continued}

\begin{tabular}{|c|c|}
\hline North Dakota & ND \\
\hline Ohio & $\mathrm{OH}$ \\
\hline Oklahoma & OK \\
\hline Oregon & OR \\
\hline Pennsylvania & PA \\
\hline Puerto Rico & PR \\
\hline Rhode Island & RI \\
\hline South Carolina & SC \\
\hline South Dakota & SD \\
\hline Tennessee & $\mathrm{TN}$ \\
\hline Texas & $\mathrm{TX}$ \\
\hline Utah & UT \\
\hline Vermont & VT \\
\hline Virgin Islands & VI \\
\hline Virginia & VA \\
\hline Washington & WA \\
\hline West Virginia & WV \\
\hline Wisconsin & WI \\
\hline Wyoming & WY \\
\hline
\end{tabular}

B. US Wind Turbines by Manufacturer (As of 2019)

\begin{tabular}{|c|c|c|}
\hline COMPANY & $\begin{array}{c}\text { NUMBER OF WIND } \\
\text { TURBINES }^{\mathrm{a}}\end{array}$ & $\begin{array}{l}\text { PERCENTAGE } \\
\text { OF TOTAL (\%) }\end{array}$ \\
\hline GE Wind & 21,174 & 41.5 \\
\hline Vestas (and Vestas North America) & 12,322 & 24.1 \\
\hline Siemens & 4901 & 9.6 \\
\hline Mitsubishi & 2796 & 5.5 \\
\hline Gamesa & 2654 & 5.2 \\
\hline Suzlon & 1306 & 2.6 \\
\hline Nordex & 929 & 1.8 \\
\hline Acciona & 758 & 1.5 \\
\hline NEG Micon & 680 & 1.3 \\
\hline Clipper & 676 & 1.3 \\
\hline Siemens Gamesa Renewable Energy & 582 & 1.1 \\
\hline REpower & 548 & 1.1 \\
\hline Bonus & 404 & 0.8 \\
\hline Enron & 396 & 0.8 \\
\hline
\end{tabular}




\section{Continued}

\begin{tabular}{|c|c|c|}
\hline Goldwind & 186 & 0.4 \\
\hline Zond & 156 & 0.3 \\
\hline Danwin & 115 & 0.2 \\
\hline Nordtank & 90 & 0.2 \\
\hline DeWind & 84 & 0.2 \\
\hline Vensys & 28 & 0.1 \\
\hline Northern Power Systems & 26 & 0.1 \\
\hline Alstom & 24 & $<0.1$ \\
\hline Fuhrlander & 19 & $<0.1$ \\
\hline China Creative Wind Energy & 17 & $<0.1$ \\
\hline Sany & 17 & $<0.1$ \\
\hline Entegrity & 16 & $<0.1$ \\
\hline HZ Windpower & 16 & $<0.1$ \\
\hline NedWind & 13 & $<0.1$ \\
\hline EWT & 11 & $<0.1$ \\
\hline Vergnet & 9 & $<0.1$ \\
\hline Seaforth Energy & 8 & $<0.1$ \\
\hline PowerWind & 7 & $<0.1$ \\
\hline Guodian & 6 & $<0.1$ \\
\hline Windmatic & 5 & $<0.1$ \\
\hline Aeronautica & 5 & $<0.1$ \\
\hline $\mathrm{RRB}$ & 5 & $<0.1$ \\
\hline TOTAL & 51,037 & 100.0 \\
\hline
\end{tabular}

${ }^{\mathrm{a}} \mathrm{Here}$ I include only those wind turbines with full confidence in characteristics $(\mathrm{n}=51,037)$ and those manufacturers with at least five turbines as of 2019. I thus exclude 22 manufacturers.

\section{Turbine Capacity by Year}

\begin{tabular}{|c|c|c|c|c|c|}
\hline YEAR & $\begin{array}{l}\text { NUMBER OF } \\
\text { NEW WIND } \\
\text { TURBINES }^{\mathrm{a}}\end{array}$ & $\begin{array}{l}\text { MEAN TURBINE } \\
\text { CAPACITY }^{\mathrm{b}} \text { (full } \\
\text { certainty) }\end{array}$ & $\begin{array}{l}\text { STANDARD } \\
\text { DEVIATION }\end{array}$ & $\begin{array}{l}\text { MEAN TURBINE } \\
\text { CAPACITYc } \\
\text { (moderate } \\
\text { certainty) }\end{array}$ & $\begin{array}{l}\text { STANDARD } \\
\text { DEVIATION }\end{array}$ \\
\hline 1981 & 10 & $\mathrm{n} / \mathrm{a}$ & $\mathrm{n} / \mathrm{a}$ & $\mathrm{n} / \mathrm{a}$ & $\mathrm{n} / \mathrm{a}$ \\
\hline 1982 & 1073 & $\mathrm{n} / \mathrm{a}$ & $\mathrm{n} / \mathrm{a}$ & 221.98 & 87.16 \\
\hline 1983 & 432 & 65 & 0.00 & $\mathrm{n} / \mathrm{a}$ & $\mathrm{n} / \mathrm{a}$ \\
\hline 1984 & 196 & 65 & 0.00 & 70.40 & 10.35 \\
\hline 1985 & 1596 & 65 & 0.00 & 95.41 & 45.32 \\
\hline 1986 & 212 & $\mathrm{n} / \mathrm{a}$ & $\mathrm{n} / \mathrm{a}$ & 107.50 & 90.19 \\
\hline 1987 & 387 & $\mathrm{n} / \mathrm{a}$ & $\mathrm{n} / \mathrm{a}$ & 101.45 & 6.51 \\
\hline 1988 & 277 & 160 & 0.00 & 105 & . \\
\hline
\end{tabular}




\section{Continued}

\begin{tabular}{|c|c|c|c|c|c|}
\hline 1989 & 288 & $\mathrm{n} / \mathrm{a}$ & $\mathrm{n} / \mathrm{a}$ & $\mathrm{n} / \mathrm{a}$ & $\mathrm{n} / \mathrm{a}$ \\
\hline 1990 & 347 & $\mathrm{n} / \mathrm{a}$ & $\mathrm{n} / \mathrm{a}$ & 218.16 & 30.02 \\
\hline 1991 & 1 & $\mathrm{n} / \mathrm{a}$ & $\mathrm{n} / \mathrm{a}$ & 225 & . \\
\hline 1992 & 2 & 250 & . & 500 & . \\
\hline 1994 & 30 & $\mathrm{n} / \mathrm{a}$ & $\mathrm{n} / \mathrm{a}$ & 490 & 20.34 \\
\hline 1995 & 44 & 225 & 0.00 & 65 & . \\
\hline 1996 & 14 & 600 & . & $\mathrm{n} / \mathrm{a}$ & $\mathrm{n} / \mathrm{a}$ \\
\hline 1997 & 231 & 65 & 0.00 & 561.43 & 181.34 \\
\hline 1998 & 189 & 722.38 & 65.25 & $\mathrm{n} / \mathrm{a}$ & $\mathrm{n} / \mathrm{a}$ \\
\hline 1999 & 1005 & 715.33 & 84.52 & 771.84 & 219.07 \\
\hline 2000 & 82 & 715.92 & 327.05 & 929.55 & 233.67 \\
\hline 2001 & 1876 & 798.19 & 254.30 & 1408.06 & 281.61 \\
\hline 2002 & 462 & 875 & 351.89 & 652.00 & 678.54 \\
\hline 2003 & 1153 & 1377.18 & 340.39 & 1482.65 & 133.48 \\
\hline 2004 & 328 & 1101.77 & 418.19 & 1321.88 & 244.12 \\
\hline 2005 & 1653 & 1488.19 & 300.88 & 1475.27 & 193.54 \\
\hline 2006 & 1506 & 1578.32 & 413.67 & 1664.01 & 398.67 \\
\hline 2007 & 3200 & 1646.23 & 420.28 & 1619.85 & 284.39 \\
\hline 2008 & 5046 & 1680.19 & 459.26 & 1488.81 & 219.71 \\
\hline 2009 & 5780 & 1732.86 & 412.07 & 1770.12 & 806.20 \\
\hline 2010 & 2960 & 1792.39 & 394.02 & 1033.80 & 858.73 \\
\hline 2011 & 3504 & 1969.19 & 459.62 & 2065.00 & 536.99 \\
\hline 2012 & 6774 & 1952 & 444.24 & 1630.35 & 353.79 \\
\hline 2013 & 610 & 1853.66 & 373.50 & 2105.56 & 592.82 \\
\hline 2014 & 2512 & 1933.34 & 358.33 & 2061.81 & 280.92 \\
\hline 2015 & 4300 & 2012.99 & 329.81 & 1828.24 & 479.47 \\
\hline 2016 & 3810 & 2157.08 & 442.62 & 1957.26 & 387.08 \\
\hline 2017 & 3090 & 2321.77 & 411.27 & $\mathrm{n} / \mathrm{a}$ & $\mathrm{n} / \mathrm{a}$ \\
\hline 2018 & 3200 & 2443.37 & 483.59 & 1525 & 1096.02 \\
\hline 2019 & 3283 & 2558.96 & 491.23 & $\mathrm{n} / \mathrm{a}$ & $\mathrm{n} / \mathrm{a}$ \\
\hline $\begin{array}{l}\text { TOTAL/A } \\
\text { VERAGE }\end{array}$ & 61463 & $1831.93^{*}$ & 604.28 & 1027.21 & 768.90 \\
\hline
\end{tabular}

${ }^{a}$ Based on all turbines regardless of turbine characteristic or location confidence $(n=61,463)$. ${ }^{b}$ include all turbines with full confidence values in turbine capacity $(n=51,036)$. ${ }^{c} I$ include all turbines with partial confidence values in turbine capacity $(n=6007)$. 


\section{New Turbines by State and Year (Decade)}

\begin{tabular}{ccccccccccc}
\multicolumn{10}{c}{$1981-1989^{\mathrm{a}, \mathrm{b}}$} \\
\hline STATE & 1981 & 1982 & 1983 & 1984 & 1985 & 1986 & 1987 & 1988 & 1989 & 1980s TOTAL \\
\hline CA & 10 & 1073 & 432 & 196 & 1596 & 212 & 387 & 277 & 288 & 4471
\end{tabular}

aI include all turbines, regardless of confidence of level, that provide a state/territory of each turbine ( $\mathrm{n}=$ 4471). ${ }^{\text {All }}$ other states/territories with zero turbines in the 1980 s are excluded within this table.

$1990-1999^{\mathrm{a}, \mathrm{b}}$

\begin{tabular}{cccccccccccc}
\hline STATE & 1990 & 1991 & 1992 & 1993 & 1994 & 1995 & 1996 & 1997 & 1998 & 1999 & 1990 s TOTAL \\
\hline CA & 347 & 1 & 1 & 0 & 30 & 42 & 13 & 207 & 2 & 187 & 830 \\
MN & 0 & 0 & 0 & 0 & 0 & 0 & 0 & 1 & 142 & 192 & 335 \\
IA & 0 & 0 & 1 & 0 & 0 & 2 & 0 & 2 & 3 & 312 & 320 \\
TX & 0 & 0 & 0 & 0 & 0 & 0 & 0 & 0 & 0 & 151 & 151 \\
WY & 0 & 0 & 0 & 0 & 0 & 0 & 0 & 0 & 2 & 108 & 110 \\
OR & 0 & 0 & 0 & 0 & 0 & 0 & 0 & 0 & 38 & 0 & 38 \\
CO & 0 & 0 & 0 & 0 & 0 & 0 & 0 & 0 & 0 & 29 & 29 \\
WI & 0 & 0 & 0 & 0 & 0 & 0 & 0 & 0 & 0 & 18 & 18 \\
AK & 0 & 0 & 0 & 0 & 0 & 0 & 6 & 0 & 6 & 0 & 12 \\
VT & 0 & 0 & 0 & 0 & 0 & 0 & 0 & 12 & 0 & 0 & 12 \\
NE & 0 & 0 & 0 & 0 & 0 & 0 & 0 & 0 & 2 & 1 & 3 \\
ND & 0 & 0 & 0 & 0 & 0 & 0 & 0 & 2 & 0 & 0 & 2 \\
IL & 0 & 0 & 0 & 0 & 0 & 0 & 0 & 1 & 0 & 0 & 1 \\
MI & 0 & 0 & 0 & 0 & 0 & 0 & 1 & 0 & 0 & 0 & 1 \\
NM & 0 & 0 & 0 & 0 & 0 & 0 & 0 & 0 & 0 & 1 & 1 \\
\hline
\end{tabular}

aI include all turbines, regardless of confidence of level, that provide a state/territory of each $(n=1863) .{ }^{b}$ All other states/territories with zero turbines in the 1990s are excluded within this table.

$2000-2009^{a, b}$

\begin{tabular}{cccccccccccc}
\hline STATE & 2000 & 2001 & 2002 & 2003 & 2004 & 2005 & 2006 & 2007 & 2008 & 2009 & 2000s TOTAL \\
\hline TX & 0 & 852 & 0 & 186 & 0 & 434 & 395 & 980 & 1694 & 1402 & 5943 \\
IA & 0 & 91 & 150 & 32 & 108 & 152 & 67 & 161 & 912 & 534 & 2207 \\
OR & 0 & 181 & 102 & 41 & 0 & 50 & 67 & 260 & 102 & 403 & 1206 \\
WA & 0 & 270 & 37 & 12 & 0 & 83 & 260 & 165 & 104 & 243 & 1174 \\
MN & 18 & 41 & 18 & 165 & 28 & 77 & 81 & 263 & 269 & 41 & 1001 \\
CA & 10 & 108 & 104 & 141 & 104 & 93 & 152 & 21 & 71 & 173 & 977 \\
IL & 0 & 0 & 0 & 0 & 1 & 34 & 0 & 358 & 129 & 430 & 952 \\
CO & 0 & 48 & 0 & 108 & 5 & 1 & 40 & 591 & 1 & 83 & 877 \\
NY & 17 & 19 & 1 & 0 & 0 & 82 & 112 & 31 & 188 & 345 & 795 \\
ND & 0 & 1 & 3 & 41 & 0 & 22 & 50 & 111 & 247 & 301 & 776 \\
OK & 0 & 1 & 0 & 113 & 0 & 182 & 40 & 85 & 91 & 154 & 666 \\
WY & 31 & 49 & 0 & 80 & 0 & 2 & 0 & 0 & 226 & 274 & 662 \\
\hline
\end{tabular}




\section{Continued}

\begin{tabular}{|c|c|c|c|c|c|c|c|c|c|c|c|}
\hline KS & 0 & 170 & 0 & 0 & 0 & 100 & 68 & 0 & 222 & 73 & 633 \\
\hline IN & 0 & 0 & 0 & 0 & 0 & 0 & 0 & 0 & 88 & 529 & 617 \\
\hline $\mathrm{NM}$ & 0 & 0 & 0 & 138 & 60 & 140 & 90 & 0 & 1 & 40 & 469 \\
\hline PA & 0 & 16 & 0 & 63 & 0 & 0 & 25 & 65 & 32 & 211 & 412 \\
\hline MT & 0 & 0 & 0 & 0 & 0 & 108 & 6 & 8 & 83 & 69 & 274 \\
\hline WI & 0 & 20 & 0 & 0 & 1 & 0 & 0 & 0 & 216 & 37 & 274 \\
\hline $\mathrm{SD}$ & 0 & 4 & 2 & 28 & 0 & 0 & 0 & 36 & 59 & 68 & 197 \\
\hline WV & 0 & 0 & 44 & 0 & 0 & 0 & 0 & 0 & 132 & 0 & 176 \\
\hline $\mathrm{MO}$ & 0 & 0 & 0 & 0 & 0 & 0 & 0 & 27 & 51 & 73 & 151 \\
\hline UT & 1 & 0 & 0 & 0 & 0 & 1 & 0 & 0 & 9 & 98 & 109 \\
\hline $\mathrm{ME}$ & 0 & 0 & 0 & 0 & 0 & 0 & 7 & 21 & 3 & 64 & 95 \\
\hline MI & 0 & 2 & 0 & 0 & 0 & 0 & 0 & 0 & 80 & 7 & 89 \\
\hline ID & 0 & 0 & 0 & 0 & 0 & 50 & 0 & 0 & 0 & 34 & 84 \\
\hline $\mathrm{NE}$ & 0 & 1 & 0 & 0 & 0 & 36 & 0 & 0 & 0 & 27 & 64 \\
\hline $\mathrm{AK}$ & 2 & 1 & 1 & 2 & 4 & 0 & 6 & 2 & 21 & 14 & 53 \\
\hline HI & 0 & 0 & 0 & 0 & 0 & 0 & 36 & 14 & 0 & 0 & 50 \\
\hline $\mathrm{AZ}$ & 0 & 0 & 0 & 0 & 0 & 0 & 0 & 0 & 0 & 30 & 30 \\
\hline MA & 0 & 1 & 0 & 0 & 0 & 1 & 2 & 1 & 3 & 13 & 21 \\
\hline $\mathrm{TN}$ & 3 & 0 & 0 & 0 & 15 & 0 & 0 & 0 & 0 & 0 & 18 \\
\hline $\mathrm{NH}$ & 0 & 0 & 0 & 0 & 0 & 0 & 0 & 0 & 12 & 1 & 13 \\
\hline $\mathrm{OH}$ & 0 & 0 & 0 & 2 & 2 & 0 & 1 & 0 & 0 & 4 & 9 \\
\hline $\mathrm{NJ}$ & 0 & 0 & 0 & 0 & 0 & 5 & 0 & 0 & 0 & 0 & 5 \\
\hline RI & 0 & 0 & 0 & 0 & 0 & 0 & 1 & 0 & 0 & 2 & 3 \\
\hline VT & 0 & 0 & 0 & 0 & 0 & 0 & 0 & 0 & 0 & 2 & 2 \\
\hline $\mathrm{AR}$ & 0 & 0 & 0 & 1 & 0 & 0 & 0 & 0 & 0 & 0 & 1 \\
\hline NC & 0 & 0 & 0 & 0 & 0 & 0 & 0 & 0 & 0 & 1 & 1 \\
\hline
\end{tabular}

${ }^{a}$ I include all turbines, regardless of confidence of level, that provide a state/territory of each $(n=21,086)$. ${ }^{b}$ All other states/territories with zero turbines in the 2000s are excluded within this table.

$2010-2019^{a, b}$

\begin{tabular}{cccccccccccc}
\hline STATE & $\mathbf{2 0 1 0}$ & $\mathbf{2 0 1 1}$ & $\mathbf{2 0 1 2}$ & $\mathbf{2 0 1 3}$ & $\mathbf{2 0 1 4}$ & $\mathbf{2 0 1 5}$ & $\mathbf{2 0 1 6}$ & $\mathbf{2 0 1 7}$ & $\mathbf{2 0 1 8}$ & $\mathbf{2 0 1 9}$ & 2010s TOTAL \\
\hline TX & 353 & 136 & 920 & 84 & 964 & 1796 & 1211 & 946 & 919 & 1429 & 8758 \\
OK & 195 & 257 & 596 & 0 & 369 & 710 & 602 & 323 & 290 & 18 & 3360 \\
IA & 5 & 282 & 385 & 26 & 219 & 226 & 304 & 195 & 506 & 690 & 2838 \\
KS & 46 & 112 & 802 & 141 & 1 & 413 & 376 & 277 & 210 & 235 & 2613 \\
IL & 284 & 405 & 493 & 0 & 0 & 153 & 93 & 139 & 233 & 161 & 1961 \\
CA & 212 & 375 & 789 & 115 & 36 & 94 & 3 & 23 & 114 & 6 & 1767 \\
CO & 35 & 262 & 308 & 18 & 153 & 232 & 36 & 36 & 300 & 35 & 1415 \\
MN & 229 & 332 & 152 & 2 & 32 & 100 & 145 & 100 & 41 & 106 & 1239 \\
\hline
\end{tabular}




\section{Continued}

\begin{tabular}{|c|c|c|c|c|c|c|c|c|c|c|c|}
\hline MI & 10 & 121 & 353 & 103 & 207 & 0 & 44 & 101 & 19 & 114 & 1072 \\
\hline ND & 128 & 9 & 80 & 1 & 65 & 118 & 311 & 124 & 45 & 145 & 1026 \\
\hline $\mathrm{NE}$ & 43 & 85 & 73 & 46 & 161 & 47 & 221 & 45 & 232 & 56 & 1009 \\
\hline OR & 129 & 209 & 253 & 0 & 0 & 0 & 6 & 25 & 0 & 56 & 678 \\
\hline NM & 64 & 28 & 14 & 5 & 21 & 134 & 16 & 260 & 22 & 84 & 648 \\
\hline IN & 184 & 1 & 128 & 1 & 101 & 65 & 0 & 106 & 61 & 0 & 647 \\
\hline WA & 162 & 158 & 119 & 0 & 117 & 2 & 0 & 0 & 0 & 0 & 558 \\
\hline SD & 229 & 51 & 0 & 0 & 11 & 98 & 0 & 0 & 18 & 83 & 490 \\
\hline ID & 134 & 155 & 168 & 0 & 0 & 0 & 0 & 0 & 0 & 0 & 457 \\
\hline $\mathrm{OH}$ & 15 & 58 & 166 & 2 & 1 & 7 & 49 & 34 & 49 & 6 & 387 \\
\hline $\mathrm{MO}$ & 101 & 0 & 1 & 0 & 1 & 0 & 92 & 165 & 0 & 24 & 384 \\
\hline NY & 2 & 67 & 78 & 52 & 16 & 6 & 40 & 7 & 77 & 1 & 346 \\
\hline PA & 0 & 21 & 279 & 0 & 0 & 0 & 14 & 0 & 5 & 20 & 339 \\
\hline $\mathrm{ME}$ & 41 & 72 & 19 & 0 & 3 & 57 & 91 & 8 & 0 & 0 & 291 \\
\hline MT & 8 & 0 & 171 & 1 & 12 & 0 & 13 & 0 & 48 & 1 & 254 \\
\hline WY & 186 & 0 & 0 & 0 & 0 & 0 & 46 & 0 & 0 & 0 & 232 \\
\hline WV & 66 & 76 & 8 & 0 & 0 & 0 & 49 & 0 & 0 & 0 & 199 \\
\hline WI & 11 & 90 & 11 & 1 & 0 & 0 & 0 & 49 & 0 & 0 & 162 \\
\hline $\mathrm{AZ}$ & 31 & 6 & 62 & 0 & 0 & 15 & 0 & 0 & 0 & 0 & 114 \\
\hline NC & 0 & 0 & 0 & 0 & 0 & 0 & 0 & 104 & 0 & 0 & 104 \\
\hline UT & 0 & 68 & 0 & 0 & 0 & 1 & 28 & 0 & 0 & 0 & 97 \\
\hline MD & 31 & 20 & 0 & 0 & 16 & 12 & 0 & 1 & 0 & 0 & 80 \\
\hline $\mathrm{AK}$ & 13 & 4 & 45 & 4 & 2 & 4 & 0 & 0 & 4 & 1 & 77 \\
\hline HI & 0 & 12 & 53 & 1 & 0 & 3 & 0 & 5 & 0 & 0 & 74 \\
\hline $\mathrm{NH}$ & 0 & 0 & 57 & 0 & 0 & 5 & 0 & 0 & 0 & 9 & 71 \\
\hline MA & 9 & 16 & 34 & 2 & 1 & 0 & 4 & 1 & 0 & 3 & 70 \\
\hline NV & 0 & 0 & 67 & 0 & 3 & 0 & 0 & 0 & 0 & 0 & 70 \\
\hline $\mathrm{PR}$ & 0 & 0 & 58 & 3 & 0 & 0 & 0 & 0 & 0 & 0 & 61 \\
\hline VT & 2 & 16 & 25 & 1 & 0 & 0 & 0 & 15 & 0 & 0 & 59 \\
\hline RI & 0 & 0 & 6 & 0 & 0 & 0 & 15 & 1 & 7 & 0 & 29 \\
\hline CT & 1 & 0 & 0 & 0 & 0 & 2 & 0 & 0 & 0 & 0 & 3 \\
\hline $\mathrm{DE}$ & 1 & 0 & 0 & 0 & 0 & 0 & 0 & 0 & 0 & 0 & 1 \\
\hline FL & 0 & 0 & 0 & 1 & 0 & 0 & 0 & 0 & 0 & 0 & 1 \\
\hline GU & 0 & 0 & 0 & 0 & 0 & 0 & 1 & 0 & 0 & 0 & 1 \\
\hline NJ & 0 & 0 & 1 & 0 & 0 & 0 & 0 & 0 & 0 & 0 & 1 \\
\hline
\end{tabular}

a I include all turbines, regardless of confidence of level, that provide a state/territory of each $(\mathrm{n}=34,043)$. ${ }^{\mathrm{b}}$ All other states/territories with zero turbines in the 2010 s are excluded within this table. 


\section{E. Total Capacity by State and Decade}

$1981-1989^{a}$

\begin{tabular}{cccccc}
\hline STATE & 1980s TOTAL b & $\begin{array}{c}\text { AVERAGE TURBINE } \\
\text { CAPACITY }(\mathrm{kW})^{\mathrm{c}}\end{array}$ & $\begin{array}{c}\text { STANDARD } \\
\text { DEVIATION }\end{array}$ & $\begin{array}{c}\text { TOTAL NEW TOTAL NEW } \\
\text { CAPACITY } \\
(\mathrm{kW})\end{array}$ & $\begin{array}{c}\text { CAPACITY } \\
(\mathrm{MW})\end{array}$ \\
\hline CA & 4471 & 79.40 & 34.08 & $354,997.40$ & 355 \\
\hline
\end{tabular}

aAll other states/territories with zero turbines in the 1980s are excluded within this table. ${ }^{b}$ I include all turbines, regardless of confidence of level, that provide a state/territory of each $(n=4,471)$. ${ }^{~ I}$ include only turbine capacities with full confidence in the $1980 \mathrm{~s}(\mathrm{n}=759)$.

$1990-1999^{a}$

\begin{tabular}{|c|c|c|c|c|c|}
\hline STATE $^{\mathrm{a}}$ & $\begin{array}{c}\text { 1990s } \\
\text { TURBINES } \\
\text { TOTAL }^{\mathrm{b}}\end{array}$ & $\begin{array}{l}\text { AVERAGE TURBINE } \\
\text { CAPACITY }(\mathrm{kW})^{\mathrm{c}}\end{array}$ & SD & $\begin{array}{c}\text { TOTAL NEW } \\
\text { CAPACITY } \\
(\mathrm{kW})\end{array}$ & $\begin{array}{c}\text { TOTAL NEW } \\
\text { CAPACITY } \\
(\mathrm{MW})\end{array}$ \\
\hline CA & 1177 & 580.38 & 212.64 & $683,107.26$ & 683.11 \\
\hline IA & 320 & 745.82 & 42.29 & $238,662.4$ & 238.66 \\
\hline $\mathrm{MN}$ & 335 & 675.71 & 196.54 & $226,362.85$ & 226.36 \\
\hline $\mathrm{TX}$ & 151 & 702.18 & 119.11 & $106,029.18$ & 106.03 \\
\hline WY & 110 & 647.73 & 68.40 & $71,250.3$ & 71.25 \\
\hline OR & 38 & 660.00 & 0.00 & 25,080 & 25.08 \\
\hline $\mathrm{CO}$ & 29 & 750.00 & 0.00 & 21,750 & 21.75 \\
\hline WI & 18 & 660.00 & 0.00 & 11,880 & 11.88 \\
\hline $\mathrm{VT}^{\mathrm{c}}$ & 12 & 545.83 & 202.77 & 6549.96 & 6.55 \\
\hline $\mathrm{NE}$ & 3 & 660.00 & 0.00 & 1980 & 1.98 \\
\hline $\mathrm{AK}$ & 12 & 74.09 & 50.59 & 889.08 & 0.89 \\
\hline $\mathrm{NM}^{\mathrm{c}}$ & 1 & 660.00 & . & 660 & 0.66 \\
\hline MI & 1 & 600.00 & . & 600 & 0.60 \\
\hline $\mathrm{IL}^{\mathrm{c}}$ & 1 & 550.00 & . & 550 & 0.55 \\
\hline $\mathrm{ND}^{\mathrm{c}}$ & 2 & 100.00 & .00 & 200 & 0.20 \\
\hline
\end{tabular}

aAll other states/territories with zero turbines in the 1990s are excluded within this table. ${ }^{\mathrm{b}} \mathrm{I}$ include all turbines, regardless of confidence of level, that provide a state/territory of each $(n=1863)$. 'I include only turbine capacities with full confidence $(n=1168)$.

\begin{tabular}{cccccc}
\multicolumn{7}{c}{$2000-2009^{a}$} \\
STATE & $\begin{array}{c}\text { 2000s } \\
\text { TURBINES } \\
\text { TOTAL }\end{array}$ & $\begin{array}{c}\text { AVERAGE } \\
\text { TURBINE } \\
\text { CAPACITY }(\mathbf{k W})\end{array}$ & $\begin{array}{c}\text { STANDARD } \\
\text { DEVIATION }\end{array}$ & $\begin{array}{c}\text { TOTAL NEW } \\
\text { CAPACITY (kW) }\end{array}$ & $\begin{array}{c}\text { TOTAL NEW } \\
\text { CAPACITY } \\
(\mathrm{MW})\end{array}$ \\
\hline TX & 5943 & 1515.71 & 530.75 & $9,007,864.53$ & 9007.86 \\
IA & 2207 & 1568.76 & 479.78 & $3,462,253.32$ & 3462.25 \\
WA & 1174 & 1613.20 & 598.88 & $1,893,896.8$ & 1893.90 \\
OR & 1206 & 1485.64 & 590.58 & $1,791,681.84$ & 1791.68 \\
MN & 1001 & 1505.24 & 389.81 & $1,506,745.24$ & 1506.75 \\
IL & 952 & 1563.88 & 170.38 & $1,488,813.76$ & 1488.81 \\
NY & 795 & 1601.16 & 285.57 & $1,272,922.2$ & 1272.92 \\
\hline
\end{tabular}




\section{Continued}

\begin{tabular}{|c|c|c|c|c|c|}
\hline CA & 977 & 1301.50 & 637.23 & $1,271,565.5$ & 1271.57 \\
\hline ND & 776 & 1585.43 & 224.97 & $1,230,293.68$ & 1230.29 \\
\hline $\mathrm{CO}$ & 877 & 1395.84 & 360.02 & $1,224,151.68$ & 1224.15 \\
\hline $\mathrm{OK}$ & 666 & 1722.03 & 307.14 & $1,146,871.98$ & 1146.87 \\
\hline WY & 662 & 1616.16 & 364.94 & $1,069,897.92$ & 1069.90 \\
\hline IN & 617 & 1678.03 & 261.68 & $1,035,344.51$ & 1035.34 \\
\hline KS & 633 & 1610.12 & 823.55 & $1,019,205.96$ & 1019.21 \\
\hline PA & 412 & 1790.53 & 309.98 & $737,698.36$ & 737.70 \\
\hline NM & 469 & 1238.02 & 460.55 & $580,631.38$ & 580.63 \\
\hline WI & 274 & 1571.23 & 119.49 & $430,517.02$ & 430.52 \\
\hline MT & 274 & 1439.05 & 289.94 & $394,299.7$ & 394.30 \\
\hline WV & 176 & 1875.00 & 217.12 & 330,000 & 330.00 \\
\hline $\mathrm{SD}$ & 197 & 1620.47 & 292.99 & $319,232.59$ & 319.23 \\
\hline MO & 151 & 2029.14 & 138.13 & $306,400.14$ & 306.40 \\
\hline UT & 109 & 2084.67 & 489.21 & $227,229.03$ & 227.23 \\
\hline $\mathrm{ME}$ & 95 & 1837.89 & 647.94 & $174,599.55$ & 174.60 \\
\hline ID & 84 & 1742.86 & 296.28 & $146,400.24$ & 146.40 \\
\hline MI & 89 & 1607.30 & 224.18 & $143,049.7$ & 143.05 \\
\hline $\mathrm{NE}$ & 64 & 2204.06 & 696.25 & $141,059.84$ & 141.06 \\
\hline $\mathrm{AZ}$ & 30 & 2100 & .00 & 63,000 & 63.00 \\
\hline $\mathrm{HI}$ & 50 & 1126.67 & 423.32 & $56,333.5$ & 56.33 \\
\hline TN & 18 & 1610.00 & 437.17 & 28,980 & 28.98 \\
\hline $\mathrm{NH}$ & 13 & 2000.00 & .00 & 26,000 & 26.00 \\
\hline MA & 21 & 926.25 & 597.45 & $19,451.25$ & 19.45 \\
\hline $\mathrm{OH}$ & 9 & 1250.83 & 852.00 & $11,257.47$ & 11.26 \\
\hline $\mathrm{AK}$ & 53 & 210.94 & 424.33 & $11,179.82$ & 11.18 \\
\hline NJ & 5 & 1500.00 & .00 & 7500 & 7.50 \\
\hline RI & 3 & 380.00 & 395.98 & 1140 & 1.14 \\
\hline $\mathrm{VT}^{\mathrm{d}}$ & 2 & 100.00 & .00 & 200 & 0.20 \\
\hline $\mathrm{AR}^{\mathrm{d}}$ & 1 & 175.83 & 330.57 & 175.83 & 0.18 \\
\hline $\mathrm{NC}^{\mathrm{e}}$ & 1 & $\mathrm{n} / \mathrm{a}$ & $\mathrm{n} / \mathrm{a}$ & $\mathrm{n} / \mathrm{a}$ & $\mathrm{n} / \mathrm{a}$ \\
\hline
\end{tabular}

${ }^{a}$ All other states/territories with zero turbines in the 2000s are excluded within this table. ${ }^{b} \mathrm{I}$ include all turbines, regardless of confidence of level, that provide a state/territory of each $(n=21,086)$. 'When available, I include only turbine capacities with full confidence $(n=18,045)$. ${ }^{\mathrm{d} F o r}$ these states, I use the average turbine capacities with moderate confidence $(n=2969)$. ${ }^{\text {eThere }}$ was no turbine capacity data for North Carolina's single turbine. 
$2010-2019^{a}$

\begin{tabular}{|c|c|c|c|c|c|}
\hline STATE & $\begin{array}{l}2010 \mathrm{~s} \\
\text { TURBINES } \\
\text { TOTAL }\end{array}$ & $\begin{array}{c}\text { AVERAGE } \\
\text { TURBINE } \\
\text { CAPACITY }(\mathrm{kW})\end{array}$ & $\begin{array}{l}\text { STANDARD } \\
\text { DEVIATION }\end{array}$ & $\begin{array}{c}\text { TOTAL NEW } \\
\text { CAPACITY } \\
(\mathrm{kW})\end{array}$ & $\begin{array}{c}\text { TOTAL NEW } \\
\text { CAPACITY } \\
(\mathrm{MW})\end{array}$ \\
\hline $\mathrm{TX}$ & 8758 & 2200.60 & 478.76 & $19,272,854.80$ & 19272.85 \\
\hline OK & 3360 & 2093.37 & 430.85 & $7,033,723.20$ & 7033.72 \\
\hline IA & 2838 & 2259.60 & 303.23 & $6,412,744.80$ & 6412.74 \\
\hline $\mathrm{KS}$ & 2613 & 2040.56 & 476.51 & $5,331,983.28$ & 5331.98 \\
\hline $\mathrm{CA}$ & 1767 & 2293.76 & 663.68 & $4,053,073.92$ & 4053.07 \\
\hline IL & 1961 & 1860.68 & 315.74 & $3,648,793.48$ & 3648.79 \\
\hline $\mathrm{CO}$ & 1415 & 1795.34 & 217.23 & $2,540,406.10$ & 2540.41 \\
\hline $\mathrm{MN}$ & 1239 & 1841.12 & 322.14 & $2,281,147.68$ & 2281.15 \\
\hline ND & 1026 & 2199.49 & 541.92 & $2,256,676.74$ & 2256.68 \\
\hline NE & 1009 & 2015.47 & 496.39 & $2,033,609.23$ & 2033.61 \\
\hline MI & 1072 & 1879.77 & 386.90 & $2,015,113.44$ & 2015.11 \\
\hline OR & 678 & 2237.86 & 389.78 & $1,517,269.08$ & 1517.27 \\
\hline NM & 648 & 2118.89 & 291.41 & $1,373,040.72$ & 1373.04 \\
\hline IN & 647 & 1972.26 & 549.34 & $1,276,052.22$ & 1276.05 \\
\hline WA & 558 & 2114.46 & 315.54 & $1,179,868.68$ & 1179.87 \\
\hline SD & 490 & 1738.42 & 240.91 & $851,825.80$ & 851.83 \\
\hline ID & 457 & 1813.14 & 332.71 & $828,604.98$ & 828.60 \\
\hline $\mathrm{OH}$ & 387 & 1996.03 & 323.75 & $772,463.61$ & 772.46 \\
\hline ME & 291 & 2590.31 & 702.21 & $753,780.21$ & 753.78 \\
\hline NY & 346 & 2159.73 & 559.10 & $747,266.58$ & 747.27 \\
\hline MO & 384 & 1873.27 & 247.18 & $719,335.68$ & 719.34 \\
\hline PA & 339 & 2049.00 & 349.15 & 694,611 & 694.61 \\
\hline MT & 254 & 1708.55 & 377.22 & $433,971.70$ & 433.97 \\
\hline WY & 232 & 1722.08 & 312.09 & $399,522.56$ & 399.52 \\
\hline wV & 199 & 1780.40 & 324.06 & $354,299.6$ & 354.30 \\
\hline WI & 162 & 1874.84 & 276.33 & $303,724.08$ & 303.72 \\
\hline NC & 104 & 2000.00 & .00 & 208,000 & 208 \\
\hline $\mathrm{AZ}$ & 114 & 1807.96 & 232.66 & $206,107.44$ & 206.11 \\
\hline MD & 80 & 2477.27 & 199.43 & $198,181.6$ & 198.18 \\
\hline $\mathrm{NH}$ & 71 & 2600.81 & 483.03 & $184,657.51$ & 184.66 \\
\hline UT & 97 & 1728.02 & 360.89 & $167,617.94$ & 167.62 \\
\hline NV & 70 & 2300.00 & .00 & 161,000 & 161 \\
\hline $\mathrm{HI}$ & 74 & 2134.78 & 605.42 & $157,973.72$ & 157.97 \\
\hline VT & 59 & 2468.97 & 599.18 & $145,669.23$ & 145.67 \\
\hline PR & 61 & 2090.42 & 467.89 & $127,515.62$ & 127.52 \\
\hline
\end{tabular}




\section{Continued}

\begin{tabular}{cccccc}
\hline MA & 70 & 1593.71 & 303.61 & $111,559.70$ & 111.56 \\
AK & 77 & 1173.94 & 764.05 & $90,393.38$ & 90.39 \\
RI & 29 & 2552.59 & 1772.13 & $74,025.11$ & 74.03 \\
CT & 3 & 2850.00 & .00 & 8550 & 8.55 \\
DE & 1 & 2000.00 & $\cdot$ & 2000 & 2 \\
NJ & 1 & 1500.00 &. & 1500 & 1.5 \\
GU & 1 & 275.00 & $\cdot$ & 275 & 0.275 \\
FL & 1 & n/a & n/a & n/a & n/a \\
\hline
\end{tabular}

${ }^{a}$ All other states/territories with zero turbines in the 2010 s are excluded within this table. ${ }^{\mathrm{b}} \mathrm{I}$ include all turbines, regardless of confidence of level, that provide a state/territory of each $(\mathrm{n}=34,043) .{ }^{\mathrm{c}}$ When available, I include only turbine capacities with full confidence $(n=31,031) .{ }^{\mathrm{d}}$ There was no turbine capacity data for Florida's single turbine.

\section{F. Size of Turbines by Year}

\begin{tabular}{|c|c|c|c|c|}
\hline YEAR & $\begin{array}{l}\text { AVERAGE HUB } \\
\text { HEIGHT }^{\mathrm{a}} \text { (metres; } \\
\text { full certainty) }\end{array}$ & $\begin{array}{l}\text { STANDARD } \\
\text { DEVIATION }\end{array}$ & $\begin{array}{l}\text { AVERAGE HUB } \\
\text { HEIGHT }^{\mathrm{b}} \text { (metres; } \\
\text { partial certainty) }\end{array}$ & $\begin{array}{l}\text { STANDARD } \\
\text { DEVIATION }\end{array}$ \\
\hline 1983 & 22.80 & 0.00 & $\mathrm{n} / \mathrm{a}$ & $\mathrm{n} / \mathrm{a}$ \\
\hline 1984 & 24.00 & 0.00 & 24 & .00 \\
\hline 1985 & 24.39 & 0.29 & $\mathrm{n} / \mathrm{a}$ & $\mathrm{n} / \mathrm{a}$ \\
\hline 1986 & $\mathrm{n} / \mathrm{a}$ & & 25.31 & 6.80 \\
\hline 1987 & $\mathrm{n} / \mathrm{a}$ & & $\mathrm{n} / \mathrm{a}$ & $\mathrm{n} / \mathrm{a}$ \\
\hline 1988 & 23.00 & .00 & $\mathrm{n} / \mathrm{a}$ & $\mathrm{n} / \mathrm{a}$ \\
\hline 1989 & $\mathrm{n} / \mathrm{a}$ & $\mathrm{n} / \mathrm{a}$ & $\mathrm{n} / \mathrm{a}$ & $\mathrm{n} / \mathrm{a}$ \\
\hline 1990 & $\mathrm{n} / \mathrm{a}$ & $\mathrm{n} / \mathrm{a}$ & 29.32 & 2.76 \\
\hline 1991 & $\mathrm{n} / \mathrm{a}$ & $\mathrm{n} / \mathrm{a}$ & $\mathrm{n} / \mathrm{a}$ & $\mathrm{n} / \mathrm{a}$ \\
\hline 1992 & 43.00 & . & 40 & . \\
\hline 1994 & $\mathrm{n} / \mathrm{a}$ & $\mathrm{n} / \mathrm{a}$ & 40 & .00 \\
\hline 1995 & 39.77 & 1.52 & 25 & . \\
\hline 1996 & 50.00 & . & $\mathrm{n} / \mathrm{a}$ & $\mathrm{n} / \mathrm{a}$ \\
\hline 1997 & 30.50 & 0.00 & 44.04 & 6.33 \\
\hline 1998 & 52.29 & 3.56 & $\mathrm{n} / \mathrm{a}$ & $\mathrm{n} / \mathrm{a}$ \\
\hline 1999 & 57.23 & 7.23 & 61.05 & 6.90 \\
\hline 2000 & 57.56 & 9.29 & 30.00 & . \\
\hline 2001 & 57.10 & 7.81 & 65.41 & 5.79 \\
\hline 2002 & 62.74 & 5.83 & 53.25 & 37.83 \\
\hline 2003 & 66.70 & 7.38 & 70.94 & 7.56 \\
\hline 2004 & 67.63 & 9.39 & 63.32 & 2.43 \\
\hline 2005 & 75.24 & 8.06 & 74.91 & 9.72 \\
\hline
\end{tabular}




\section{Continued}

\begin{tabular}{ccccc}
\hline 2006 & 74.30 & 9.51 & 78.67 & 4.61 \\
2007 & 77.77 & 5.16 & 79.65 & 2.25 \\
2008 & 78.14 & 4.77 & 78.61 & 7.45 \\
2009 & 78.85 & 3.98 & 70.71 & 15.29 \\
2010 & 79.79 & 2.25 & 65.89 & 21.86 \\
2011 & 80.89 & 5.58 & 80.40 & 5.91 \\
2012 & 83.75 & 9.26 & 82.61 & 7.01 \\
2013 & 80.23 & 3.55 & 86.50 & 9.49 \\
2014 & 82.85 & 5.61 & 79.65 & 3.81 \\
2015 & 82.30 & 5.39 & 87.71 & 17.27 \\
2016 & 82.98 & 6.02 & 88.05 & 18.73 \\
2017 & 86.01 & 6.69 & $\mathrm{n} / \mathrm{a}$ & $\mathrm{n} / \mathrm{a}$ \\
2018 & 88.26 & 5.87 & 80 &. \\
2019 & 90.30 & 6.88 & $\mathrm{n} / \mathrm{a}$ & $\mathrm{n} / \mathrm{a}$ \\
TOTAL/ & 79 & 11.72 & 70.96 & 17.54 \\
AVERAGE & & & & \\
\hline
\end{tabular}

${ }^{\text {aI }}$ include all turbines with full confidence values in hub height $(\mathrm{n}=51,035)$. ${ }^{\mathrm{b} I}$ include all turbines with partial confidence values in hub height turbine $(\mathrm{n}=4168)$.

\section{G. Largest Turbines by Year (Hub Height; 2000-2019)}

\begin{tabular}{cc}
\hline YEAR & TALLEST TURBINE (HUB HEIGHT; METRES) \\
\hline 2000 & 67 \\
2001 & 80 \\
2002 & 80 \\
2003 & 80 \\
2004 & 80 \\
2005 & 85 \\
2006 & 80 \\
2007 & 105 \\
2008 & 100 \\
2009 & 80 \\
2010 & 100 \\
2011 & 100 \\
2012 & 100 \\
2013 & 103 \\
2014 & 100 \\
2015 & 100 \\
2016 & 16.5 \\
& \\
\hline & \\
\hline
\end{tabular}




\section{Continued}

\begin{tabular}{cc}
\hline 2017 & 95 \\
2018 & 130 \\
2019 & 114 \\
TOTAL/AVERAGE & 79 \\
\hline
\end{tabular}

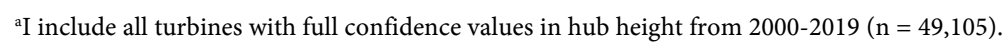

\section{H. Turbine Rotor Diameter and Swept Area (1999-2019)}

\begin{tabular}{|c|c|c|c|c|}
\hline YEAR & $\begin{array}{l}\text { AVERAGE ROTOR } \\
\text { DIAMETER (metres; } \\
\text { full certainty) }\end{array}$ & $\begin{array}{l}\text { STANDARD } \\
\text { DEVIATION }\end{array}$ & $\begin{array}{l}\text { AVERAGE TOTAL } \\
\text { SWEPT AREA (metres }{ }^{2} ; \\
\text { full certainty) }\end{array}$ & $\begin{array}{l}\text { STANDARD } \\
\text { DEVIATION }\end{array}$ \\
\hline 1999 & 48.22 & 3.08 & 1833.71 & 195.30 \\
\hline 2000 & 47.15 & 8.18 & 1798.27 & 598.58 \\
\hline 2001 & 50.36 & 6.35 & 2023.83 & 549.64 \\
\hline 2002 & 52.48 & 8.97 & 2226.36 & 813.07 \\
\hline 2003 & 68.36 & 8.57 & 3727.21 & 885.81 \\
\hline 2004 & 62.11 & 13.89 & 3170.71 & 1307.07 \\
\hline 2005 & 74.78 & 9.33 & 4460.39 & 904.72 \\
\hline 2006 & 76.71 & 10.76 & 4711.93 & 1192.97 \\
\hline 2007 & 78.70 & 9.11 & 4929.53 & 1099.01 \\
\hline 2008 & 79.28 & 9.93 & 5014.22 & 1154.89 \\
\hline 2009 & 81.36 & 8.42 & 5254.04 & 1039.99 \\
\hline 2010 & 84.22 & 7.67 & 5617.48 & 1024.65 \\
\hline 2011 & 88.92 & 8.93 & 6272.06 & 1196.47 \\
\hline 2012 & 93.62 & 10.65 & 6972.71 & 1488.44 \\
\hline 2013 & 96.87 & 9.15 & 7435.97 & 1178.05 \\
\hline 2014 & 99.59 & 7.40 & 7832.87 & 1131.63 \\
\hline 2015 & 102.29 & 7.98 & 8267.02 & 1246.57 \\
\hline 2016 & 108.26 & 7.57 & 9250.39 & 1267.75 \\
\hline 2017 & 112.99 & 7.08 & 10066.30 & 1204.18 \\
\hline 2018 & 115.96 & 8.09 & 10611.66 & 1489.73 \\
\hline 2019 & 122.63 & 7.18 & 11850.43 & 1374.05 \\
\hline $\begin{array}{c}\text { TOTAL/AV } \\
\text { ERAGE }\end{array}$ & 90.81 & 19.14 & 6764.93 & 2654.08 \\
\hline
\end{tabular}

${ }^{\mathrm{a}}$ include all turbines with full confidence values in rotor diameter and total swept area $(\mathrm{n}=51,035)$ 